\title{
10. MINERALOGY AND GEOCHEMISTRY OF SEDIMENTS FROM GALAPAGOS HYDROTHERMAL MOUNDS, LEG 70, DEEP SEA DRILLING PROJECT ${ }^{1}$
}

\author{
V. B. Kurnosov and O. V. Chudaev, Far East Geological Institute, Vladivostok, USSR \\ and \\ A. YA. Shevchenko, Institute of Oceanology, Moscow, USSR
}

\section{INTRODUCTION}

Clay minerals recovered from the Galapagos hydrothermal mounds (Holes 506C, 507D, and 509B) are mainly iron-rich nontronite-like minerals enriched in potassium. Nontronites from Hole 509B show a distinct tendency to become micaceous toward the lower beds of clay sediments.

Mn-crusts consist mainly of todorokite or a mixture of todorokite and nontronite. Minerals of clay and Mnrich sediments in the mounds originated from hydrothermal solutions of uncertain origin.

Pelagic oozes from hydrothermal mounds and from areas between mounds (Hole 506D) consist mainly of calcite. In the carbonate beds on or near the hydrothermal mounds an admixture of smectite is often found.

\section{METHODS}

Sediment fractions $<2 \mu \mathrm{m}, 2-20 \mu \mathrm{m},>20 \mu \mathrm{m}$, and the bulk of sediments from the area of Galapagos hydrothermal mounds were analyzed by X-ray diffraction, electron microscopy, electron diffraction, and infrared spectroscopy. Chemical and spectral analyses were also made.

A DRON-1.5 X-ray diffractometer with $\mathrm{CuK}_{\alpha}$ radiation and a $\mathrm{Ni}$ filter was used. We examined both oriented and unoriented specimens. Each sample was air-dried, treated with ethylene glycol, and heated at 500 to $550^{\circ} \mathrm{C}$ for $1 \mathrm{hr}$. Some clay fractions were treated with $10 \% \mathrm{HCl}$ at 90 to $100^{\circ} \mathrm{C}$ for $1 \mathrm{hr}$. and also with $1 \mathrm{~N} \mathrm{~K}_{2} \mathrm{CO}_{3}$.

To determine the ordering of bedded structures we used electron diffraction analysis. We studied nontronites by electron microdiffraction. The morphology of clay minerals and their relation to other mineral phases were analyzed using a UEMV-100K electron microscope and an ISM-U3 scanning electron microscope.

We identified nontronite and nontronite-like minerals using a UR-20 infrared spectrometer. A tablet mixture of the specimen and $\mathrm{KBr}$ in a ratio of $1: 300$ was used.

\section{RESULTS}

Nontronite-like minerals, calcite, todorokite, fairchildite(?), mica, a 7- $\AA$ mineral, quartz, feldspar, and phillipsite were identified in sediments recovered from the Galapagos hydrothermal area.

\section{Mineral Composition}

Thirty-six samples of hydrothermal and carbonate sediments recovered from the area of the mounds were studied in fractions $<2 \mu \mathrm{m}, 2-20 \mu \mathrm{m},>20 \mu \mathrm{m}$ (Table

\footnotetext{
${ }^{1}$ Honnorez, G., Von Herzen, R. P., et al., Init. Repts. DSDP, 70: Washington (U.S. Govt. Printing Office).
}

1), and in bulk. These sediments were recovered from four holes: 506C, 507D, and 509B (mounds) and 506D (between mounds).

The mineral composition of hydrothermal clay sediments is rather monotonous. Often these sediments consist almost entirely of nontronite-like minerals (Table 1). Sometimes hydromica, a $7-\AA$ mineral, quartz, feldspar, fairchildite, and phillipsite occur as admixtures. A mixed-layer mineral with different ratios of packets of ferruginous smectite and celadonite (glauconite) prevails in Samples 506C-3-2, 31-32 cm; 509B-3-3, 4-6 cm; and 509B-5-3, 83-85 cm.

Previous investigations (Corliss et al., 1978) discovered that iron-rich smectite-nontronite was a primary mineral of hydrothermal sediments. Our investigation revealed the composition of clay minerals more precisely (Fig. 1).

Among sediments recovered from hydrothermal mounds, three types of clay minerals can be distinguished as follows:

1) An air-dried specimen of Sample 506C-2-2, 46-48 $\mathrm{cm}$ is characterized by a strong first-order basal reflection at $15.5 \AA$ (Fig. 1); reflections of subsequent orders do not always appear. The saturation of the specimen with ethylene glycol results in a shift of the first reflection to $17.7 \AA$; reflections of the second order appear as a broad diffuse peak at $9 \AA$. After heating at $550^{\circ} \mathrm{C}$, interlayer water is removed, resulting in the appearance of the first basal reflection at $9.7 \AA$. The reflection of the second order is absent, possibly as a result of the high iron content of the mineral. To reveal structural peculiarities, the sample was saturated with $1 \mathrm{~N} \mathrm{~K}_{2} \mathrm{CO}_{3}$ solution for $48 \mathrm{hr}$. After treating the mineral with potassium, the first basal reflection became distinct at $d_{(001)}$ $=11 \AA$. After saturating the specimen (previously saturated with potassium) with ethylene glycol, the diffraction pattern became peculiar. The partially preserved mineral retained the ability to swell, and the diffraction patterns showed a sharp asymmetric reflection at $d_{(001)}$ $=17.7 \AA$, while the other part of the mineral stopped swelling. After heating the sample, two distinct reflections appeared: at $9.8 \AA$ and $3.30 \AA$. One interpretation is that the mineral in question is a high-ferruginous smectite of nontronite-type with a heterogeneous interlayer structure. Some packets seem to have acquired a mica-type structure. The mineral is dioctahedral.

2) When air-dried, the reflection of Sample 506C$3-2,31-32 \mathrm{~cm}$, which occurs farther down in the section, 
Table 1. Mineral composition of sediments from Galapagos hydrothermal mounds, Leg 70.

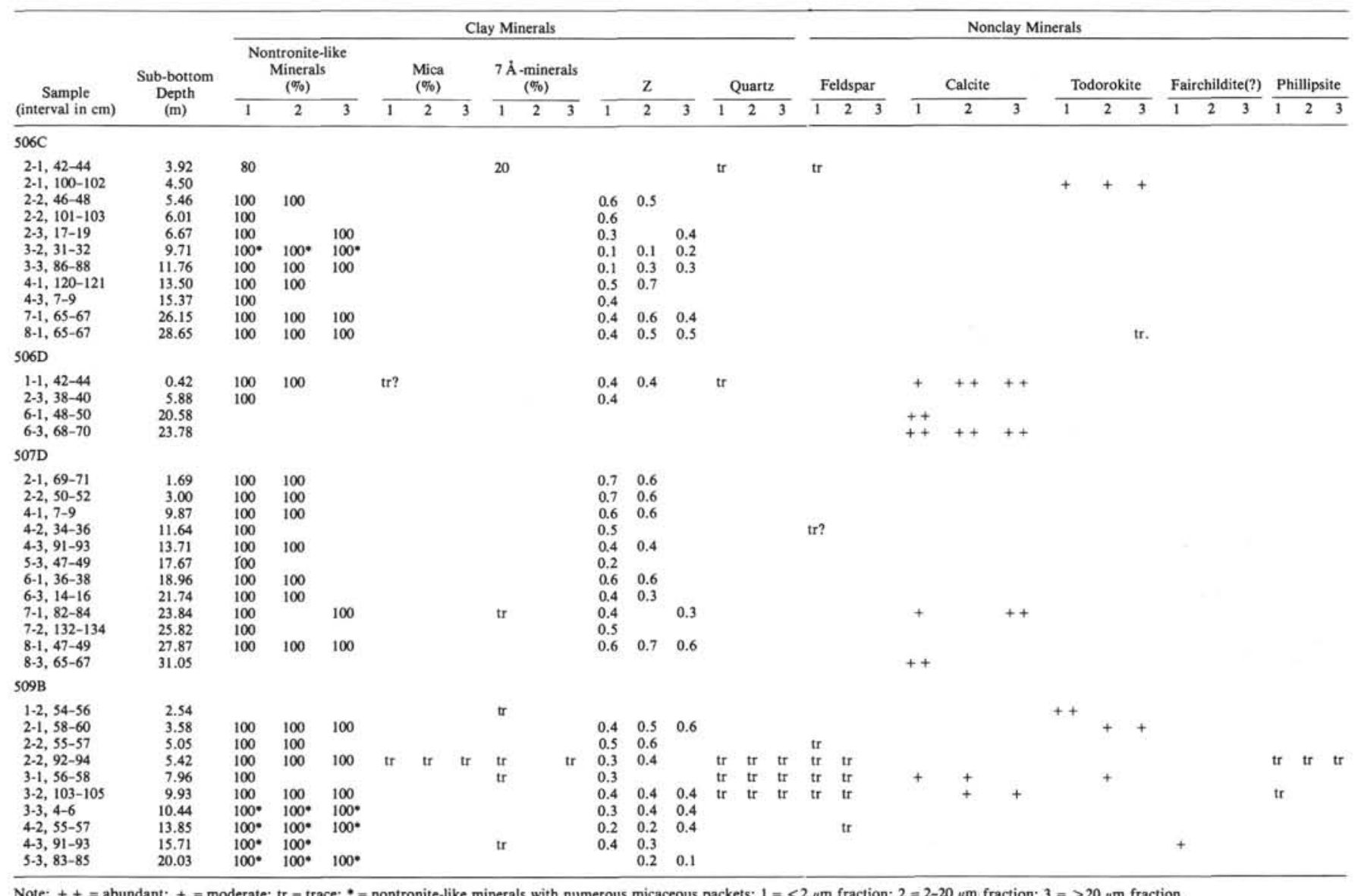

is at $10.6 \AA$, suggesting a high potassium content in the interlayers. Chemical analysis of the sample supports this hypothesis (Table 2). The saturation of the mineral with ethylene glycol causes the shift of 001 reflection to $17.7 \AA$, with a sharp asymmetric reflection appearing in this area. A second-order reflection appears as a diffused peak at $9.3 \AA$. After heating the sample, two distinct reflections appear at $d_{(001)}=10 \AA$ and $d_{(003)}=3.3 \AA$. As in the previous sample, a second-order reflection is absent after the sample has been heated. The b-parameter of the mineral is equal to $9.06 \AA$ (Table 3). The mineral saturated with potassium lacks the ability to swell in ethylene glycol-that is, it becomes a typical mineral of the celadonite (glauconite) group. Chemical analysis shows that the mineral is characterized by high iron and potassium content (Table 2), while the alumina content is simultaneously low. The b-parameter allows us to suggest a rather insignificant substitution of silicon for iron in tetrahedrons. The charge of the layer concentrates mainly in octahedrons because of the nonstoichiometric substitution of $\mathrm{Fe}^{3+}$ for $\mathrm{Mg}^{2+}$. The magnesium oxide content of the sample is rather high $(3.20 \%)$. Thus, unlike Sample 506C-2-2, 46-48 cm, this mineral is characterized by numerous mica-type packets-reaching $40 \%$, judging by the reflection $d_{(002)}=9.3 \AA$. It is a mixedlayer mineral of nontronite-celadonite (glauconite) type. The composition of the other clay sediment samples from Hole $506 \mathrm{C}$ is similar to that of Sample 506C-2-2, $46-48 \mathrm{~cm}$.
3) In Hole 509B a nontronite-like mineral is identified in a shallow bed (Sample 509B-2-1, 58-60 cm), its diffraction characteristics being similar to those of Sample 506C-2-2, 46-48 cm (Fig. 1). At the bottom of the hole (Sample 509B-5-3, 83-85 cm) an almost micaceous mineral of celadonite-glauconite type with a small quantity of swelling smectite interlayers (Fig. 1) is found. Sample 509B-3-3, 4-6 cm takes an intermediate position and is similar to Sample 506C-3-2, 31-32 cm. Samples 509B-5-3, 83-85 cm and 509B-3-3, 4-6 cm do not exhibit swelling with potassium when treated by ethylene glycol. Potassium content in Sample 509B-5-3, 83-85 cm $(3.34 \%)$ is higher than in Sample 509B-3-3, 4-6 cm $(2.90 \%)$ (Table 2). It is possible that Sample 509B-5-3, $83-85 \mathrm{~cm}$ represents the end member in the process of "micatization" of nontronite interlayers, which proceeds downward in the hydrothermal sediment sections.

As a rule, scanning electron micrographs show finedispersed, elongated particles of nontronite (Plate 1, Figs. 1-3). Long lath-shaped smectite particles are found among the fine-dispersed elongated particles of Sample 506C-2-3, 17-19 cm.

Scanning electron micrographs also show the various morphologies of nontronite-like minerals (Plate 2).

These smectites have much in common with smectites from the Red Sea (Butuzova et al., 1977, 1979).

Nontronite-like minerals from Hole 509B contain many more mica packets in the lower beds of clay sediments (in the range from 10-20 m) than are present in 


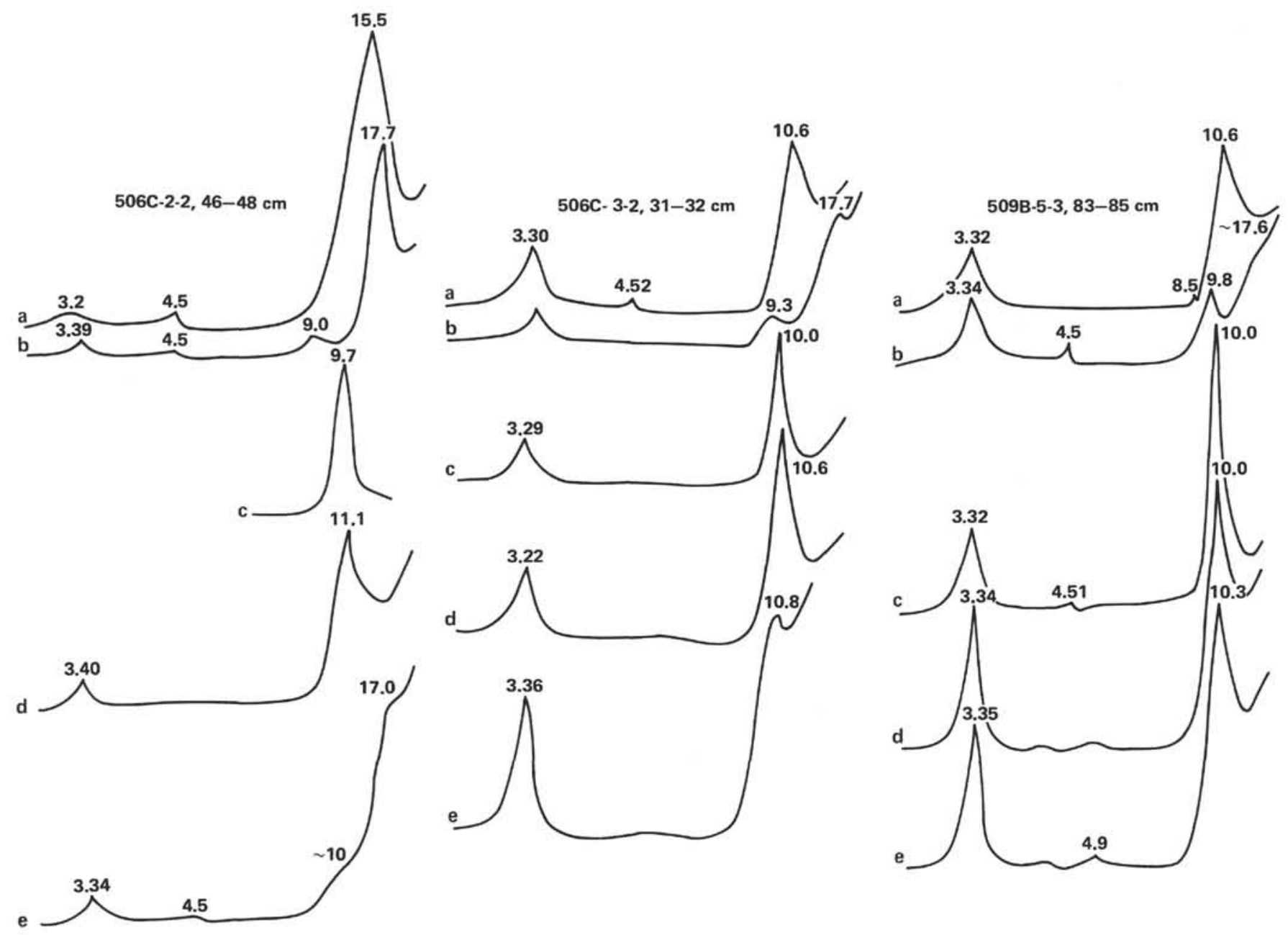

Figure 1. X-ray diffraction patterns of smectites of the main types $(<2 \mu \mathrm{m}$ fraction) from sediments of the Galapagos hydrothermal mounds.

Table 2. Wet chemical analyses (wt.\%) of sediments from Galapagos hydrothermal mounds, Leg 70.

\begin{tabular}{|c|c|c|c|c|c|c|c|c|c|c|c|c|c|c|c|c|c|c|c|c|c|}
\hline \multirow{2}{*}{$\begin{array}{c}\text { Sample } \\
\text { (interval in } \mathrm{cm} \text { ) } \\
\text { Compound }\end{array}$} & \multirow{2}{*}{$\begin{array}{l}506 \mathrm{C}-2-1 \\
-42-44 \mathrm{~cm} \\
1\end{array}$} & \multirow{2}{*}{$\begin{array}{c}506 \mathrm{C}-2-1 \\
100-102 \mathrm{~cm}\end{array}$} & \multirow{2}{*}{$\begin{array}{c}506 \mathrm{C}-2-2, \\
46-48 \mathrm{~cm}\end{array}$} & \multicolumn{2}{|c|}{$\begin{array}{c}506 \mathrm{C}-3 \cdot 2 \\
31-32\end{array}$} & \multirow{2}{*}{$\begin{array}{c}\begin{array}{c}506 C-8-1 \\
65-67\end{array} \\
1\end{array}$} & \multicolumn{2}{|c|}{$\underset{50-52}{507 D-2-2}$} & \multirow{2}{*}{$\begin{array}{c}\begin{array}{c}\text { 507D-5-2, } \\
33-35\end{array} \\
1\end{array}$} & \multicolumn{2}{|c|}{$\underset{47-49}{507 \mathrm{D}-8-1}$} & \multirow{2}{*}{$\begin{array}{c}\begin{array}{c}507 \mathrm{D}-9-2, \\
80-83\end{array} \\
1\end{array}$} & \multirow{2}{*}{$\begin{array}{c}\begin{array}{c}509 \mathrm{~B}-1 \cdot 2 \\
54-56\end{array} \\
1\end{array}$} & \multicolumn{2}{|c|}{$\begin{array}{c}5098-2-1, \\
58-60\end{array}$} & \multicolumn{2}{|c|}{$\begin{array}{c}509 \mathrm{~B}-3-3 \\
4-6\end{array}$} & \multicolumn{2}{|c|}{$\begin{array}{c}509 \mathrm{~B}-4 \cdot 2, \\
55-57\end{array}$} & \multicolumn{2}{|c|}{$\begin{array}{c}509 \mathrm{~B}-5 \cdot 3, \\
83-85\end{array}$} \\
\hline & & & & 1 & 3 & & 1 & 3 & & 1 & 3 & & & 1 & 3 & 1 & 3 & 1 & 3 & 1 & 3 \\
\hline $\mathrm{SiO}_{2}$ & 17.76 & 26.57 & & 46.17 & 48.08 & 40.12 & 42.05 & 45.27 & 42.96 & 40.94 & 46.41 & 7.58 & 2.19 & 38.17 & 40.42 & 46.03 & 47,04 & 37.23 & 35.76 & 37.90 & 43.73 \\
\hline $\mathrm{TiO}_{2}$ & 0.18 & 0.01 & & 0.02 & 0.02 & 0.03 & 0.02 & 0.03 & 0.02 & 0.02 & 0.07 & 0.08 & 0.04 & 0.03 & 0.04 & 0.02 & 0.02 & 0.06 & 0.09 & 0.06 & 0.12 \\
\hline $\mathrm{Al}_{2} \mathrm{O}_{3}$ & 4.78 & 0.27 & 1.00 & 0.20 & 0.26 & 0.51 & 0.28 & 0.22 & 0.43 & 0.47 & 0.66 & 2.06 & 0.36 & 0.64 & 1.05 & 0.50 & 0.24 & 0.67 & 1.21 & 0.56 & 1.07 \\
\hline $\mathrm{Fe}_{2} \mathrm{O}_{3}$ & 2.40 & 16.23 & 27.25 & 24.02 & 26.15 & 22.11 & 23.26 & 27.36 & 21.67 & 23.33 & 24.31 & 1.30 & 0.55 & 20.42 & 24.63 & 23.31 & 25.68 & 21.57 & 30.12 & 18.59 & 24.40 \\
\hline $\mathrm{FeO}$ & 0.37 & 0.37 & 0.92 & 1.27 & 0.75 & 0.50 & 0.47 & 1.12 & 0.90 & 1.02 & 0.55 & 0.60 & 0.30 & 0.45 & 0.75 & 1.02 & 0.67 & 0.32 & 0.65 & 1.42 & 0.55 \\
\hline $\mathrm{MnO}$ & 34.97 & 23.81 & & 0.09 & 0.13 & 0.51 & 0.07 & 0.11 & 0.07 & 0.15 & 0.2 & 0.19 & 58.36 & 3.02 & 0.18 & 0.09 & 0.10 & 0.25 & 0.29 & 0.13 & 0.18 \\
\hline $\mathrm{MgO}$ & 3.34 & 1.61 & & 3.19 & 3.20 & 3.04 & 2.44 & 2.08 & 3.64 & 2.68 & 2.84 & 1.13 & 3.43 & 4.07 & 3.24 & 3.08 & 3.47 & 3.48 & 3.00 & 4.11 & 4.07 \\
\hline $\mathrm{CaO}$ & 0.46 & 0.93 & & 0.39 & 0.31 & 5.05 & 0.55 & 0.45 & 1.17 & 3.05 & 2.04 & 43.18 & 0.62 & 3.11 & 1.40 & 0.39 & 0.62 & 0.57 & 1.14 & 6.18 & 1.65 \\
\hline $\mathrm{Na}_{2} \mathrm{O}$ & 4.50 & 2.67 & 0.28 & 1.78 & 0.29 & 2.08 & 2.92 & 0.19 & 2.43 & 2.07 & 0.21 & 2.32 & 2.83 & 2.26 & 0.30 & 1.48 & 0.30 & 4.02 & 0.33 & 2.10 & 0.32 \\
\hline $\mathrm{K}_{2} \mathrm{O}$ & 0.94 & 1.46 & 1.53 & 3.30 & 2.67 & 2.34 & 1.60 & 0.92 & 2.98 & 1.86 & 1.47 & 0.38 & 0.94 & 1.67 & 1.45 & 3.18 & 2.90 & 2.07 & 1.26 & 3.42 & 3. \\
\hline $\mathrm{P}_{2} \mathrm{O}_{5}$ & 0.22 & 0.24 & & 0.28 & 0.32 & 0.24 & 0.31 & 0.32 & 0.30 & 0.24 & 0.31 & 0.13 & 0.26 & 0.29 & 0.28 & 0.21 & 0.30 & 0.24 & 0.30 & 0.30 & $\begin{array}{l}0.27 \\
8.35\end{array}$ \\
\hline $\mathrm{H}_{2} \mathrm{O}^{-}$ & 13.10 & 12.81 & & 12.32 & 8.31 & 14.11 & 18.52 & 11.83 & 14.64 & 14.92 & 8.50 & 2.52 & 10.62 & 14.59 & 5.51 & 13.14 & 10.04 & 18.53 & 10.01 & 12.44 & $\begin{array}{r}8.35 \\
20.42\end{array}$ \\
\hline Loi & 30.19 & 25.55 & & 19.49 & 17.69 & 23.60 & 26.24 & 22.24 & 23.46 & 24.04 & 20.74 & 41.15 & 30.21 & 26.07 & 26.47 & 20.88 & 18.89 & 29.91 & 26.10 & 25.18 & 20.42 \\
\hline Total & 100.11 & 99.72 & & 100.20 & 99.87 & 100.13 & 100.21 & 100.31 & 100.03 & 99.87 & 99.88 & 100.10 & 99.79 & 100.20 & 100.29 & 100.19 & 100.23 & 100.39 & 100.25 & 99.95 & 100.12 \\
\hline
\end{tabular}

Note: 1 = bulk: $2=2-20 \mu \mathrm{m}$ fraction; $3=<2 \mu \mathrm{m}$ fraction.

Table 3. The b-parameter of smectites from sediments of Galapagos hydrothermal mounds, Leg 70.

\begin{tabular}{lcc}
\hline $\begin{array}{c}\text { Sample } \\
\text { (interval in cm) }\end{array}$ & $\begin{array}{c}\text { Sub-bottom } \\
\text { Depth } \\
(\mathrm{m})\end{array}$ & $\mathrm{b}(\AA)$ \\
\hline Hole 506C & & \\
$2-3,17-19$ & 6.67 & 9.07 \\
$3-2,31-32$ & 9.71 & 9.06 \\
$4-1,120-121$ & 13.50 & 9.08 \\
$7-1,65-67$ & 26.15 & 9.06 \\
\hline
\end{tabular}

the upper part of the section. Such regularity was not determined in Hole 506C. Numerous mica packets in nontronite were found only in Sample 506C-3-2, 31-33 $\mathrm{cm}$, recovered from a depth of 9.7 meters. In Hole 507D sediments containing nontronites with numerous mica packets were not found at all. All the samples of clay sediments from Hole 507D consist mainly of nontronite with a small admixture of mica packets, similar to those studied in Sample 506C-2-2, 46-48 cm.

$\mathrm{X}$-ray diffraction patterns of hydrothermal sediments show a very weak reflection at $7 \AA$, making it difficult to identify the mineral. In some cases it may be chlorite. 
A rather strong reflection at $7.06 \AA$, attributed to chlorite, and reflections at $4.7 \AA$ and $3.5 \AA$ appear on X-ray diffraction patterns of Sample 506C-2-1, 42-44 cm. Chlorite(?) occurs most often in sediments from Hole 509B.

Hydromica is identified by a weak reflection near 10 $\AA$; it is identified with certainty only in Sample 509B2-2, 92-94 cm (Table 1).

Weak reflections near 7 and $3.16 \AA$ suggest the presence of phillipsite in sediments recovered from Hole 509B (Plate 3, Figs. 2-4). In Sample 509B-4-3, 91-93 $\mathrm{cm}$, a reflection at $3.19 \AA$ identifies a group of potassic carbonates (fairchildite?). Ashes are rarely observed in clay hydrothermal sediments (Plate 3, Fig. 1).

Quartz (3.34 and $4.25 \AA$ ) and feldspar ( $3.20 \AA$ ) occur most often in clay sediments from the middle part of Hole 509B.

Interlayers of manganese crusts consist mainly of todorokite. It has peculiar reflections at 9.6 and $4.8 \AA$. In addition, Mn-crusts include nontronite-like minerals. Chlorite, clinoptilolite, feldspar, quartz, and cristobalite were identified in Sample 506C-2-1, 42-44 cm, enriched in Mn. (Fig. 5 of Plate 3 shows the structure of cristobalite. The morphology of particles $<2 \mu \mathrm{m}$ is shown in Plate 1, Fig. 4. Plate 3, Fig. 6 shows the general structure of a sediment.)

Pelagic ooze interbedded with hydrothermal sediments consists of calcite and often contains a nontronite-like mineral. The sediments between the mounds are mainly calcareous.

\section{Chemical Composition}

Table 2 shows the chemical composition of sediments from the Galapagos hydrothermal area. Clay sediments are enriched in $\mathrm{Fe}_{2} \mathrm{O}_{3}$ and impoverished in $\mathrm{Al}_{2} \mathrm{O}_{3}, \mathrm{FeO}$, and $\mathrm{TiO}_{2} ; \mathrm{K}_{2} \mathrm{O}$ content is also high. In fractions $<2 \mu \mathrm{m}$, there are small increases in $\mathrm{Fe}_{2} \mathrm{O}_{3}, \mathrm{Al}_{2} \mathrm{O}_{3}, \mathrm{SiO}_{2}$, and $\mathrm{K}_{2} \mathrm{O}$ and sharp decreases in $\mathrm{Na}_{2} \mathrm{O}$ compared with clay sediments on the whole. High $\mathrm{Fe}_{2} \mathrm{O}_{3}$ and low $\mathrm{Al}_{2} \mathrm{O}_{3}$ content allows us to regard the smectites as nontronites. Manganese-bearing sediments contain up to $58 \% \mathrm{MnO}$ (Sample 506C-2-1, 42-44 cm and 100-102 cm, and Sample 509B-1-2, 54-56 cm).

The highest content of $\mathrm{MnO}, \mathrm{MgO}$, and $\mathrm{Na}_{2} \mathrm{O}$ in hydrothermal sediments is found in Hole 509B. High $\mathrm{K}_{2} \mathrm{O}$ content $(>3 \%)$ appears in clay sediments consisting mainly of mixed-layer minerals and is spread throughout Holes 506C and 509B.

Table 4 shows the trace element content in sediments recovered from the Galapagos area. Clay sediments from hydrothermal mounds are enriched in boron, evenly distributed in different granulometric fractions. $\mathrm{Ag}, \mathrm{Zn}$, and $\mathrm{Cu}$ concentrate mainly in the 2 to $20 \mu \mathrm{m}$ fractions and in the $<2 \mu \mathrm{m}$ fraction. In Hole 509B, the $\mathrm{Cu}, \mathrm{B}, \mathrm{Ni}$, $\mathrm{V}, \mathrm{Zn}$, and $\mathrm{Ag}$ content of the clay minerals increases downwards.

In Mn-crust from Hole 509B (Sample 509B-1-2, 54$56 \mathrm{~cm}$; $\mathrm{MnO}$ content $=58.36 \%) \mathrm{Cu}, \mathrm{Ni}, \mathrm{Ag}$, and especially Mo increase and B decreases as compared with clay sediments. In Mn-crust from Hole 506C (Sample
506C-2-1, 42-44 cm; MnO content $=34.97 \%$ - as compared with that of Hole 509B-Co, Cr, Ni, V, and especially $\mathrm{Zn}$ increase and Mo decreases. The content of trace elements in Sample 506C-2-1, 100-102 cm (MnO content $=23.81 \%$ ) is intermediate between that in clay sediments and that in manganese crust-i.e., this sample is a clay sediment enriched in manganese.

\section{FORMATION OF SEDIMENTS}

Data on mineral and chemical composition of sediments recovered from and between hydrothermal mounds suggest the following mode of accumulation. In the Galapagos area, mainly carbonate foraminiferal nannofossil sediments are accumulating and, together with less-common pelagic clays, make up the regional sediment cover. These sediments were recovered from holes drilled between the mounds. Within the mounds area, zones of weakness (faults and fractures) have developed within the crust, which have the same trend as the axis of the Galapagos Rift. These zones are characterized by a high heat flow (up to 23 HFU) and often have a form of mounds reaching 20 meters and more.

Foraminiferal ooze accumulated as a rule on a basaltic basement. Hydrothermal activity on these faulted zones promoted the accumulation of hydrothermal sediments. When the supply of hydrothermal solutions ceased, foraminiferal ooze again accumulated. Every time the hydrothermal activity resumed, the solutions passed through sediments, and hydrothermal minerals accumulated along with the foraminiferal nannofossil ooze.

Nontronite-like minerals were formed from the interaction of hydrothermal solutions containing $\mathrm{SiO}_{2}, \mathrm{Fe}$, and other cations with near-bottom or pore seawater. This resulted in oxidation of iron and deposition of (mainly) iron-rich smectite under conditions close to those described by Bishoff (1974) and obtained in experiments by Harder (1973). Additional treatment of this specimen with hydrothermal solution resulted in additional capture of potassium and an increase in the number of mica packets in its structure. Figure 2 shows the composition of nontronite-like minerals of different origin. The figure shows that nontronites and nontronite-like minerals are very low in $\mathrm{Al}_{2} \mathrm{O}_{3}$, according to our data and that of other authors (see Fig. 2).

Hydrothermal solutions are responsible for the formation of manganese crusts. The different geochemical behaviors of iron and manganese are obvious. Iron oxidizes quickly and is deposited, forming nontronites. Oxidation of manganese proceeds more slowly; the element thus remains mobile and is deposited only if there is a large amount of oxidizing agent, forming crusts of manganese oxide.

One may explain the origin of solutions enriched in $\mathrm{Mn}, \mathrm{Fe}$, and some trace elements by secondary alteration of the basaltic basement upon contact with seawater (Mottl et al., 1979). Underlying basalts occurring in a very high heat-flow zone are considerably altered, or hydrothermal sediments are deposited mainly from hydrothermal solutions. The increase in $\mathrm{K}$ downward in 
the hydrothermal sediments in Hole 509B probably results from endogeneous solutions.

Hydrothermal activity in the Galapagos mounds area reveal a uniform hydrothermal activity that results in the formation of nontronite-like minerals and Mn-crusts. A precise study of the mineralogical and chemical composition of hydrothermal sediments from Holes 506C, 507D, and 509B shows that hydrothermal activity in various mounds differs.

Sediments from Hole 509B show the most intensive hydrothermal activity. In the lower part of the sediments, a group of $\mathrm{K}$-minerals was formed (mixed-layer hydromica-smectite mineral, fairchildite, phillipsite, and feldspar that is probably potassic and may also be detrital). This part of the core contains the greatest amounts of $\mathrm{K}_{2} \mathrm{O}(3.42 \%)$. Sediments from this hole also contain the most $\mathrm{MgO}(4.11 \%)$ and $\mathrm{Na}_{2} \mathrm{O}(4.02 \%)$. Either hydrothermal solutions were most intensely delivered, or they were more enriched in $\mathrm{K}$.

A comparison of the chemical compositions of Mncrusts from Holes 506C and 509B suggests that hydrothermal solutions had different compositions at different areas in the Galapagos mounds. Manganese crust from Hole $506 \mathrm{C}$ is highly enriched in $\mathrm{Zn}$ and impoverished in Mo compared with that of Hole 509B.

\section{ACKNOWLEDGMENTS}

We thank T. I. Bortina, T. V. Sverkunova, L. I. Kovbas, G. A Narnov, N. V. Ryapolova, and G. A. Yudina, both for their help with the analyses and with developing the manuscript. We also thank Dr. N. N. Pertsev and Prof. H. Okada, who reviewed the chapter.

\section{REFERENCES}

Bishoff, J., 1974. Sediments of hydrothermal brines of the Red Sea. In Degens, E. T., and Ross, D. A. (Eds.), Hot Brines and Recent Heavy Metal Deposits in the Red Sea: Moscow (Mir), pp. 157-193. (in Russian)

Butuzova, G. Yu, Drits, V. A., Lisitsina, N. A., Tsipursky, S. I., and Dmitrik, A. L., 1979. Dynamics of clay minerals formation in orebearing sediments of the Atlantis-II basin. Lithol. Miner. Resour., $1: 30-42$.

Butuzova, G. Yu., Lisitsina, N. A., Gradusov, B. P., Dmitrik, A. L., and Chizhikova, N. P., 1977. On the origin of clay minerals in orebearing sediments of the Red Sea. Rept. Acad. Sci. USSR, 236(1): 192-195.

Corliss, I., Lyle, M., Dymond, I., and Crave, K., 1978. The chemistry of hydrothermal mounds near the Galapagos rift. Earth Planet. Sci. Lett., 40:12-24.

Harder, H., 1976. Nontronite synthesis at low temperatures. Chem. Geol., 18:169-180.

Isphording, W., 1975. Primary nontronite from Venezuelan Guyana. Am. Mineral., 60(9-10):840-848.

Mottl, M. J., Holland, H. D., and Corr, R. F., 1979. Chemical exchange during hydrothermal alteration of basalt by seawater, II. Experimental results for $\mathrm{Fe}, \mathrm{Mn}$, and sulfur species. Geochim. Cosmochim. Acta, 43(6):869-884. 


\section{B. KURNOSOV, O. V. CHUDAEV, A. YA. SHEVCHENKO}

Table 4. Trace elements (ppm) of sediments from Galapagos hydrothermal mounds, Leg 70.

\begin{tabular}{|c|c|c|c|c|c|c|c|c|c|c|c|c|c|c|c|c|c|}
\hline \multirow{2}{*}{$\begin{array}{c}\begin{array}{c}\text { Sample } \\
\text { (interval in cm) }\end{array} \\
\text { Element }\end{array}$} & \multicolumn{3}{|c|}{$\begin{array}{c}506 \mathrm{C}-2-1, \\
42-44\end{array}$} & \multicolumn{3}{|c|}{$\begin{array}{c}506 C-2-1, \\
100-102\end{array}$} & \multicolumn{2}{|c|}{$\begin{array}{c}506 \mathrm{C}-3-2 \\
31-32\end{array}$} & \multirow{2}{*}{$\begin{array}{c}506 C-4-1 \\
120-121 \\
1\end{array}$} & \multirow{2}{*}{$\begin{array}{c}506 C-7-1, \\
65-67\end{array}$} & \multicolumn{2}{|c|}{$\begin{array}{c}506 C-8-1, \\
65-67\end{array}$} & \multicolumn{2}{|c|}{$\begin{array}{c}507 \mathrm{D}-2-2, \\
50-52\end{array}$} & \multicolumn{2}{|c|}{$\begin{array}{c}507 \mathrm{D}-3-3, \\
74-76\end{array}$} & \multirow{2}{*}{$\begin{array}{c}507 D-4-3 \\
91-93\end{array}$} \\
\hline & 1 & 2 & 3 & 1 & 2 & 3 & 1 & 2 & & & 1 & 3 & 1 & 2 & 1 & 2 & \\
\hline B & 50 & 35 & 45 & 100 & 100 & 150 & 130 & 120 & 83 & 100 & 150 & 150 & 130 & 140 & 150 & 160 & 140 \\
\hline Co & 20 & 20 & 15 & 20 & 10 & 6 & - & - & - & 5 & 40 & 2 & 1 & 1 & 2 & 4 & 1 \\
\hline $\mathrm{Cr}$ & 30 & 40 & 40 & 15 & 10 & 10 & - & 9 & 6 & 10 & 8 & 6 & 4 & - & 8 & 16 & 5 \\
\hline $\mathrm{Cu}$ & 200 & 250 & 250 & 150 & 250 & 200 & 22 & 270 & 25 & 46 & 450 & 71 & 20 & 100 & 43 & 300 & 32 \\
\hline Mo & 150 & 85 & 30 & 350 & 250 & 250 & - & - & - & 20 & 40 & 10 & - & - & - & - & - \\
\hline $\mathrm{Ni}$ & 250 & 300 & 150 & 15 & 25 & 10 & 5 & 10 & 9 & 30 & 35 & 25 & 7 & 10 & 22 & 34 & 17 \\
\hline V & 100 & 85 & 100 & 45 & 35 & 45 & 14 & 18 & 24 & 30 & 35 & 26 & 18 & 17 & 42 & 55 & 30 \\
\hline $\mathrm{Pb}$ & - & - & 90 & - & - & - & 3 & 4 & - & 35 & 60 & 4 & 3 & 4 & 3 & 11 & 3 \\
\hline $\mathrm{Sn}$ & - & 2 & 2 & - & - & - & 4 & 6 & 4 & - & - & 5 & 4 & 12 & 3 & 6 & 4 \\
\hline $\mathrm{Zn}$ & 75 & 600 & 400 & - & 200 & 85 & 27 & 150 & 190 & 27 & 35 & 110 & 31 & 100 & 70 & 320 & 56 \\
\hline $\mathrm{Ag}$ & - & 10 & 3 & - & 6 & 3 & 0.33 & 4.7 & 0.33 & 0.30 & 0.30 & 2.6 & 0.04 & 0.56 & 0.04 & 1.6 & 0.14 \\
\hline
\end{tabular}

Note: $1=$ bulk; $2=2-20 \mu \mathrm{m}$ fraction; $3=<2 \mu \mathrm{m}$ fraction.

Table 4. (Continued).

\begin{tabular}{|c|c|c|c|c|c|c|c|c|c|c|c|c|c|c|c|c|c|}
\hline \multirow{2}{*}{$\begin{array}{c}\begin{array}{c}\text { Sample } \\
\text { (interval in cm) }\end{array} \\
\text { Element }\end{array}$} & \multirow{2}{*}{$\begin{array}{c}\text { 507D-5-2, } \\
33-35 \\
1\end{array}$} & \multicolumn{3}{|c|}{$\begin{array}{c}507 \mathrm{D}-8-1, \\
47-49\end{array}$} & \multirow{2}{*}{$\begin{array}{c}507 \mathrm{D}-9-2 \\
80-83 \\
1\end{array}$} & \multicolumn{3}{|c|}{$\begin{array}{c}509 \mathrm{~B}-1-2 \\
54-56\end{array}$} & \multicolumn{3}{|c|}{$\begin{array}{c}509 \mathrm{~B}-2-1, \\
58-60\end{array}$} & \multicolumn{2}{|c|}{$\begin{array}{c}509 \mathrm{~B}-4-6, \\
4-6\end{array}$} & \multicolumn{2}{|c|}{$\begin{array}{c}509 \mathrm{~B}-4-2 \\
55-57\end{array}$} & \multicolumn{2}{|c|}{$\begin{array}{c}509 \mathrm{~B}-5-3 \\
83-85\end{array}$} \\
\hline & & 1 & 2 & 3 & & 1 & 2 & 3 & 1 & 2 & 3 & 1 & 3 & 1 & 2 & 1 & 2 \\
\hline B & 140 & 140 & 150 & 140 & 5 & 50 & 40 & 50 & 150 & 150 & 150 & 190 & 190 & 130 & 170 & 250 & 230 \\
\hline $\mathrm{Co}$ & 1 & 3 & 3 & 2 & 3 & - & - & - & 4 & 3 & 2 & 1 & 2 & 2 & 4 & 3 & 6 \\
\hline $\mathrm{Cr}$ & 4 & 7 & 3 & 8 & - & - & - & - & - & - & 4 & 4 & 5 & 2 & 11 & 2 & 3 \\
\hline $\mathrm{Cu}$ & 19 & 33 & 50 & 70 & 65 & 200 & 150 & 300 & 45 & 150 & 100 & 8 & 30 & 85 & 440 & 45 & 330 \\
\hline Mo & - & 150 & 5 & 13 & - & 600 & 600 & 750 & 40 & 35 & 15 & - & - & - & 5 & - & - \\
\hline $\mathrm{Ni}$ & 11 & 18 & 21 & 20 & 25 & 45 & 100 & 60 & 25 & 55 & 25 & 12 & 18 & 18 & 51 & 56 & 80 \\
\hline V & 16 & 30 & 36 & 31 & 35 & 20 & 35 & 55 & 35 & 40 & 20 & 6 & 10 & 23 & 33 & 51 & 72 \\
\hline $\mathrm{Pb}$ & - & 11 & 11 & 3 & - & - & - & - & 80 & 70 & 60 & - & 3 & - & 4 & 4 & 3 \\
\hline Sn & 4 & 6 & 9 & 6 & 2 & - & - & - & - & - & 4 & 4 & 6 & 2 & 11 & 2 & 3 \\
\hline $\mathrm{Zn}$ & 27 & 54 & 96 & 96 & - & - & - & - & - & - & - & 22 & 67 & 50 & 48 & 36 & 300 \\
\hline $\mathrm{Ag}$ & 0.05 & 0.10 & 0.60 & 0.61 & 0.15 & - & 15 & 0.35 & - & 2 & 1 & - & 0.55 & 0.03 & 4.0 & 0.07 & 3.7 \\
\hline
\end{tabular}

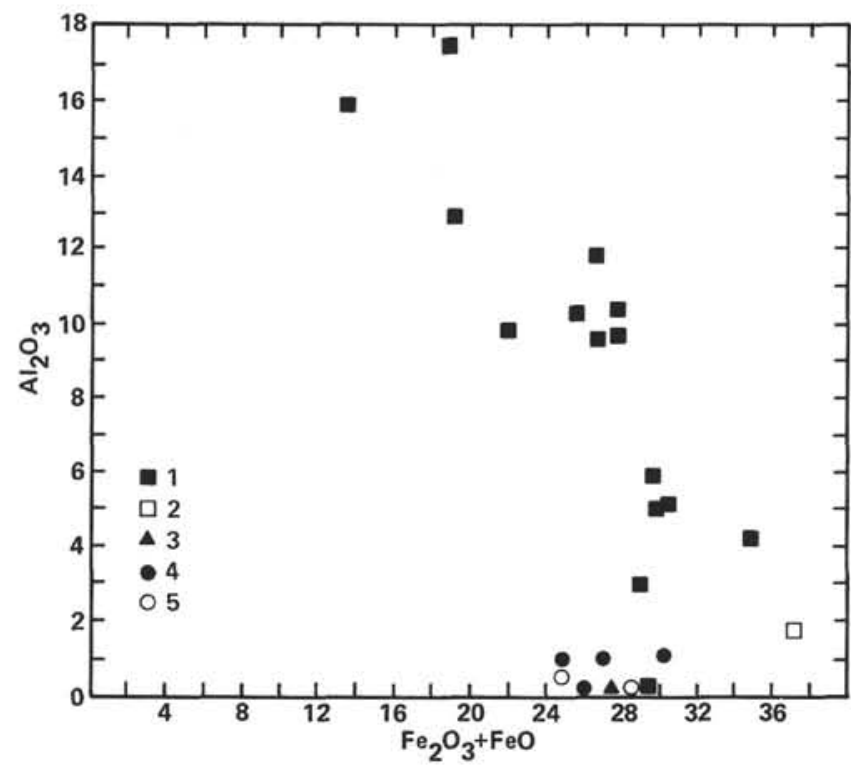

Figure 2. Ratios of $\mathrm{Al}_{2} \mathrm{O}_{3}$ vs. $\mathrm{Fe}_{2} \mathrm{O}_{3}+\mathrm{FeO}$ nontronites of different origin. 1 = nontronites [Isphording, 1975]; $2=$ nontronites from Red Sea [Bishoff, 1974]; $3=$ Hole 506C; $4=$ Hole 509B; $5=$ Hole 507D. 

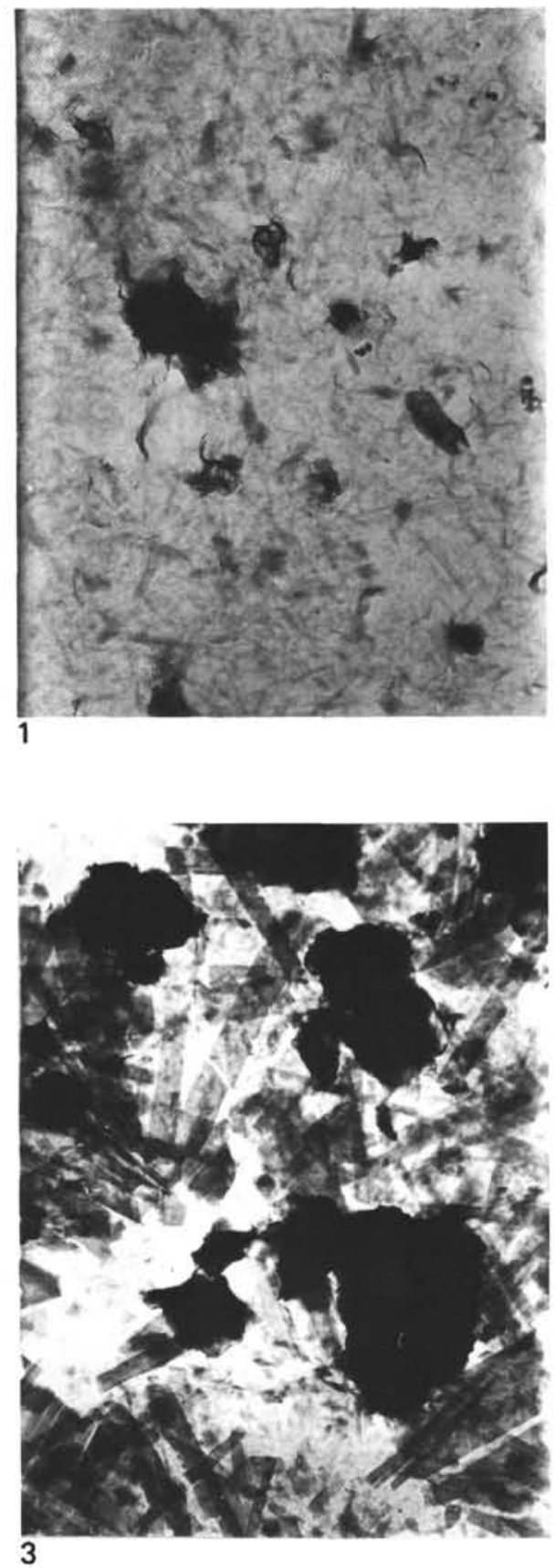
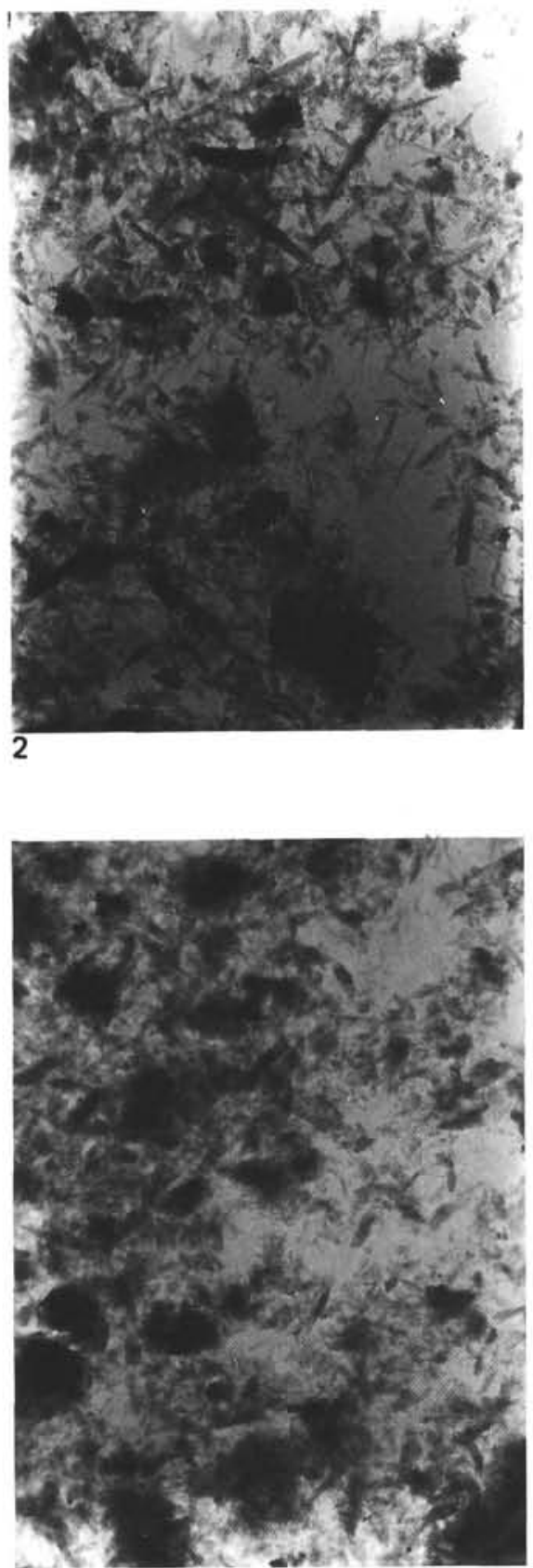

4

Plate 1. Electron micrographs of nontronite-like minerals from Leg 70 hydrothermal sediments ( $<2 \mu \mathrm{m}$ fraction). 1. Sample $506 \mathrm{C}-4-1,120-127$ $\mathrm{cm}(\times 10,500)$. 2. Sample 509B-5-3, 83-85 cm $(\times 10,000)$. 3. Sample 506C-2-3, 17-19 cm $(\times 8000)$. 4. Sample 509B-3-3, 4-6 cm $(\times 8000)$. 


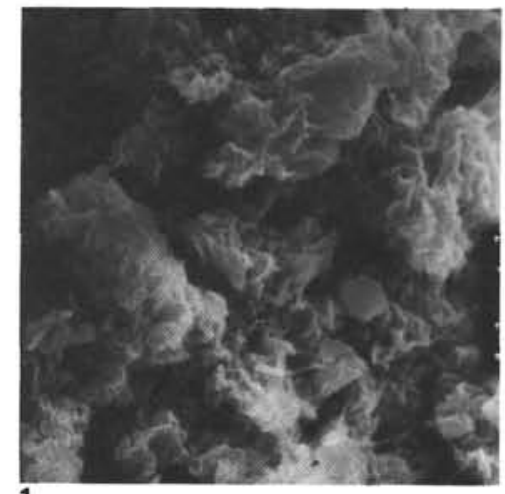

1

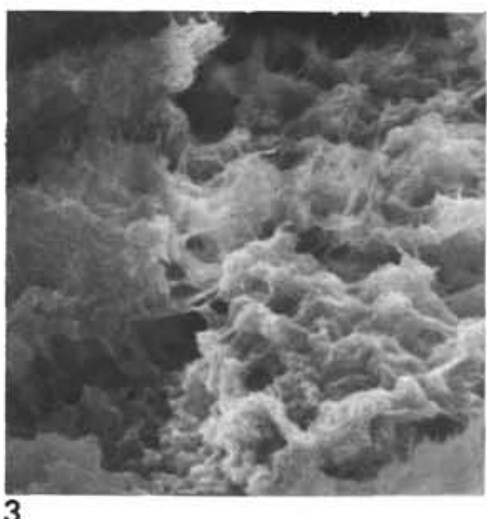

3

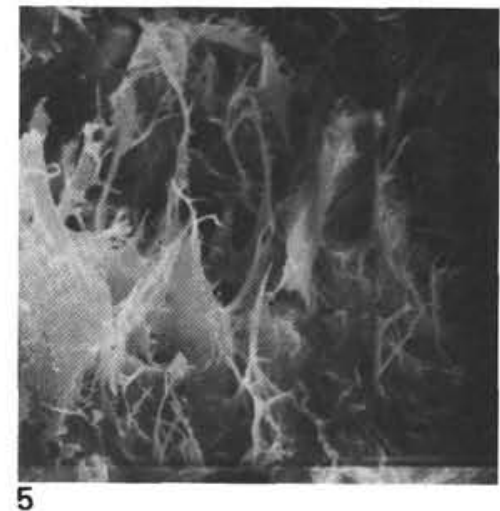

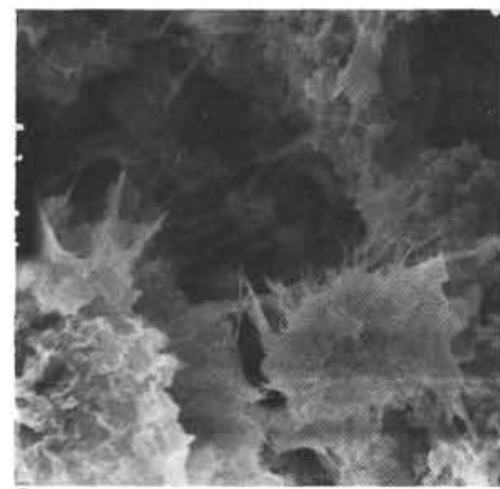

2

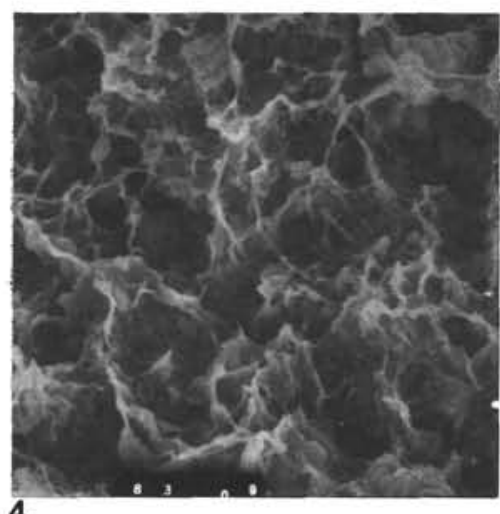

4

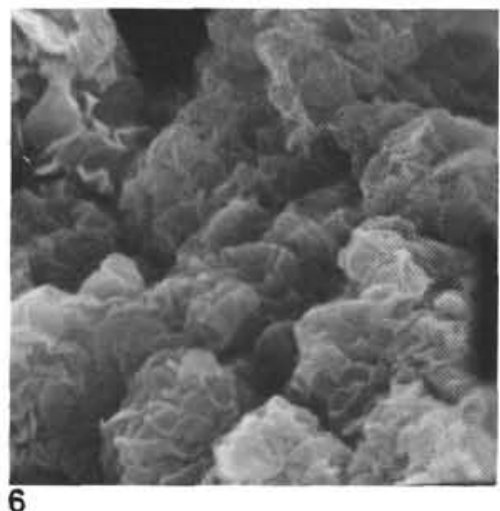

Plate 2. Electron microscope photos of hydrothermal clay sediments (nontronite-like minerals). 1. Nontronite; hexagonal crystal in center; Sample 506C-2-3, 17-19 cm $(\times 1500)$. 2. Hair-like nontronite in pores of a sediment; Sample 506C-2-3, 17-19 cm $(\times 1000)$. 3. Spongeous nontronite with a hair-like surface; Sample 506C-2-3, 17-19 cm $(\times 1500)$. 4. Spongeous surface of a sediment with prevailing mixed-layer hydromica-smectite mineral; Sample 509B-5-3, 83-85 cm $(\times 500)$. 5. Hair-like structure of a mixed-layer mineral; Sample 509B-5-3,83-85 cm $(\times 1500)$. 6. Structure of nontronite-like mineral; Sample 509B-4-3, 91-93 cm $(\times 3000)$. 

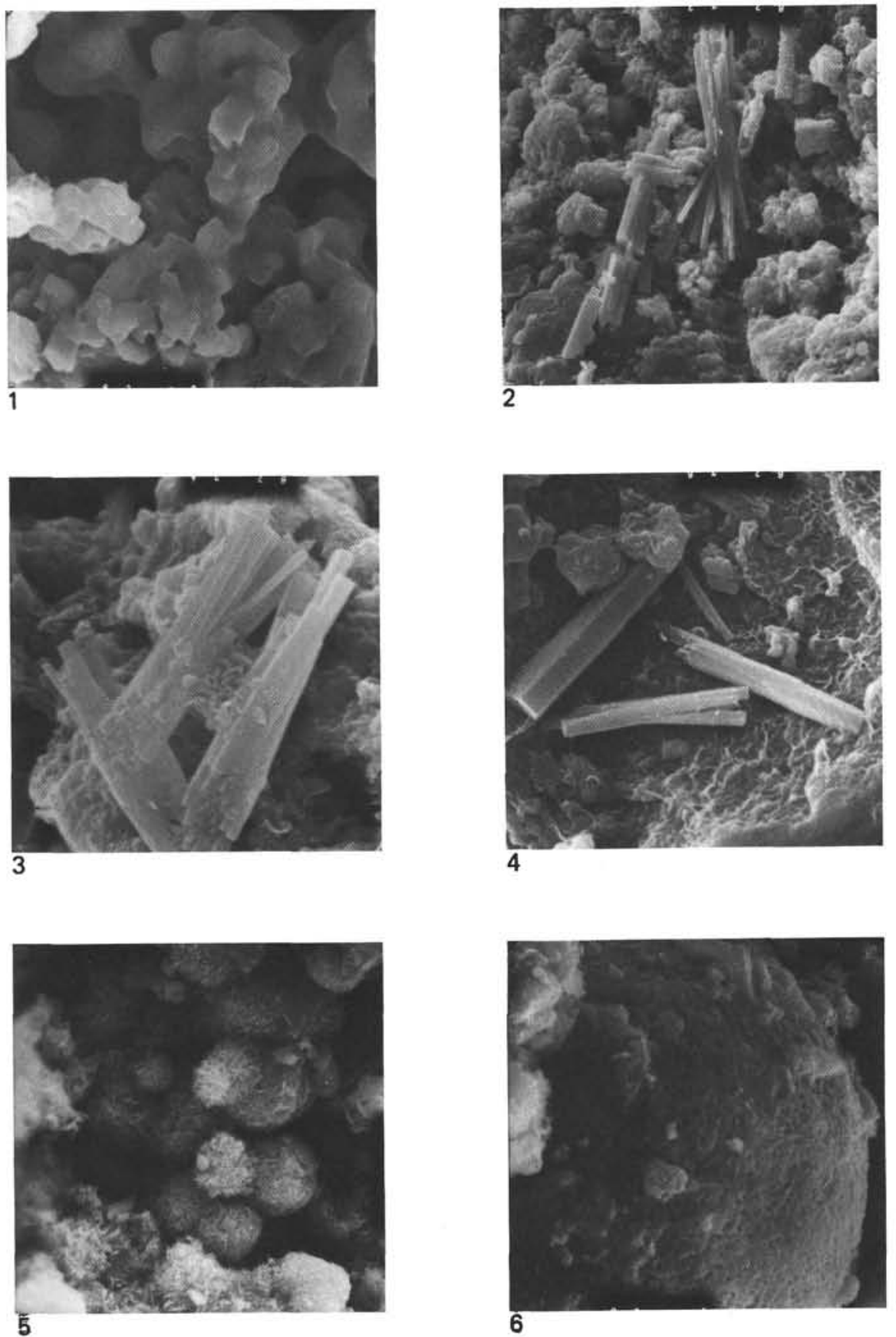

Plate 3. Electron microscope photos of hydrothermal clay and Mn-crusts. 1. Sinter varieties; Sample 509B-4-3, 91-93 cm $(\times 300)$. 2. Zeolites(?) in clay sediment; Sample 506C-3-2, 31-32 cm $(\times 500)$. 3. Same sample as Fig. 2. $(\times 1500)$. 4. Same sample as Fig. 2. $(\times 1000)$. 5. Cristobalite globules in Mn-crust; Sample 506C-2-1, 42-44 cm $(\times 1000)$. 6. Surface of Mn-crust; Sample 506C-2-1, 100-102 cm $(\times 1000)$. 